\title{
Society \& Economy of Rampa Tribes of Andhra Pradesh: A Fertile Ground for Revolts
}

\author{
Dr. B.R. Prasad Reddy, \\ Reader in History, K. H. Government Degree College, Dharmavaram, Anantapuramu District, Andhra Pradesh.
}

\section{Introduction}

It is heartening that recent historiography is disproving the hypothesis of Barrington Moore and others of that ilk, that subaltern revolts were relatively rare and completely ineffective and related this apparent passivity to the peculiarities of the Indian social and economic system, particularly to the caste system and selfsufficient economic set up. However, though interest in peasant and tribal struggles is of fairly recent origin, yet, it has shown that there, indeed, has been a long tradition of revolt and protest among peasants and tribes. This paper tries to focus the nature of tribal society and economy in the Rampa tracts of Andhra region of erstwhile Madras Presidency, which was docile and dormant and yet responded vibrantly to the interference and domination of colonial power, i.e., the British in the $19^{\text {th }}$ century. This study of their society and economy prior to 1879-80 tribal revolt in Rampa is an attempt to further enhance our understanding of such revolts and protests.

Rampa, Rekapalli, Gudem, Madgula, Dustarti and Pachipenta regions consisting of thick forests, hills and broad valleys forming part of Madras Presidency witnessed a violent tribal revolt during 1879-80. Rampa was situated at a distance of 3 miles to the north of Chodavaram and thirty seven miles from Rajahmundry, now located in East Godavari district. Rampa consisting of hills of about 4000 feet high in thick forests in the then Godavari district became part of Madras Presidency in 1766. Chodavaram, the head quarter of Rampa region, was bound on the south and west by Godavari River. The whole area was occupied by the Eastern Ghats and forests covered nearly 575 sq. miles.

The social structure of the Rampa tribes was similar to the egalitarian structure of tribal groups in general. ${ }^{1}$ However; the polity of the hill men was hierarchical. At the apex of this polity stood the Mansabdar followed by the Muttadar and below the latter were the rest of the tribes. It is probably that during $14^{\text {th }}$ century the tribal population in the hill was brought under superficial control of Reddy kings and that the system of tribal chieftain (now described as Muttadar) was instituted or if already existing, recognized by the Reddy rulers.

At the time of the cession of the Northern Circars to the East India Company, the Rampa country was in the possession of ruling chief alternatively styled Zamindar or Mansabdar or Raja. ${ }^{2}$ Earlier records describe the Rampa Mansabdar as independent ruler, though he was himself not a Reddy or Koya, the Muttadars recognized him as their over-lord. How the Rampa Mansabdar originally gained possession of the country and by what means he succeeded in controlling the independent and elusive hill people is not known. It is likely that when adventurous bands (now reigning as Muttadars) invaded the hills with the tacit approval of the Raja of the plains, the Muttadars in return might have agreed to act as his subordinates and recognized him as overlord. The term Mansabdar was a late arrival but which was familiar from the time of the Mughals. The Mansabdar exercised primarily dejure supremacy over the hills and never intervened in the internal affairs. The interior mountainous region of Rampa enjoyed relative freedom. ${ }^{3} \mathrm{He}$, however, exercised minimal control in revenue collection, revenues which were rather meager.

Haimendorf feels that the Muttadari system which had a considerable influence on tribal life was superimposed. ${ }^{4}$ The origin of the Muttadari system is obscure, but it was firmly established in the region by the time of British arrival. ${ }^{5}$ Conditions in the Godavari region, given the general level of material culture and the extreme independence of the individual in economic and social enterprise, the probability of a strict organization based on feudal principle having at any time enfolded the whole tribe seems unlikely. The Muttadari system might have therefore, resulted from extraneous influence which penetrated the more inaccessible Rampa Country.

These external elements might have possessed somewhat higher material culture and a social organization far more developed than that of the original tribal population. However, it should be noted that the immigrants after settling in the region established themselves as chiefs and collected tribute in kind. Gradually they were assimilated into the tribal society and were cut off from the low and civilization. By the $19^{\text {th }}$ century, they were so fully assimilated that all traces of a non-tribal identity, disappeared. This penetration was in striking contrast to the intrusion of the $19^{\text {th }}$ century, when the very foundations of tribal society were shaken. 
Having entered the tribal region and established themselves as Muttadars, the intruders became part and parcel of tribal society.

The average Muttadar was no tyrant and interfered little with his subject's freedom of action. The availability of adequate jungle land made it easier for the hill men to escape from direct control. The settlements of all minor disputes were left to the normal village panchayat, and the Muttadar intervened as a rule only when he was called by the Headman. The chain of contact Headman and Muttadar extended the Muttadar's influence into even the remotest villages.

Celebration of feasts and his presence during festivals brought him much closer to his subjects. He entertained men and women with food and grain on such occasions. It should be noted that the Muttadars depended not on any legal right but on the actual influence they exercised over village communities. ${ }^{6}$

The Muttadar, though politically above his subjects, socially he was considered one among the tribals. Inter dining and inter-marriage was common. He made little attempt to alter the independent style of living. There were no restrictions on the hill men in expressing their opinion in the democratic social organization which allowed every individual to follow his whims as long as these did not conflict with the interest of his fellow tribesmen. Though the Muttadar paid fixed revenue to the Mansabdar it was a very insignificant amount. ${ }^{7}$ The Muttadar traditionally commanded great respect and exercised considerable influence and control over his villages. He had to maintain law and order, settle disputes, organize ceremonies, perform rituals and act as a link between the hill men and their overlord, the Mansabdar. All these functions established his power over the hill people who accepted his sovereignity. ${ }^{8}$

However, even before the advent of the Muttadari system, there was a compact and coherent social organization in Rampa country based on "Village Communities" and "Clans". A village community was the most important territorial unit in the hills. ${ }^{9}$ It may number only four or five households all concentrated in one place, or it may comprise as many as twenty-five or thirty families distributed over several settlements. The heads of the village settlements were either born in the locality which ensured their membership in the community and their rights in the land were acquired automatically or they had migrated to the village with the common consent of the rest of the community.

In the villages where hill Reddies and Koyas lived side by side in fairly equal numbers, each community recognized its own headman and priest. When the numbers of either tribe pre-dominated, their headman represented the whole village. The atmosphere within the village community was intensely democratic. Each member had equal rights.

The position of the headman was a hereditary one and was held by the village founder. The chief function of the headman was mainly a religious one. He acted both as the headman and the priest. He, with the consent of Muttadar, performed festivals and funerals. He enjoyed no special privileges and exercised no authority over his fellow villagers. He presided over the Panchayat, and all his decisions had to be endorsed by the whole community. The main function of the hereditary head of the village was that of mediator between man and the supernatural powers, as priests. He performed those rites and ceremonies that were believed to secure the prosperity of the community as a whole. And since this prosperity was intimately linked with the thriving of the crops, it was above all the agricultural rites that called for the intercession of the priest. He inaugurated the sowing of the grains, propitiated the earth deity with sacrifices and performed rites at the great annual feasts, where the Muttadar in his capacity entertained men and women with food and grain and drinks. Thus, equality and reciprocity were the basis of tribal, social interaction and relationships. ${ }^{10}$

The basic social unit was the "Clan". Though the village community and clan were two intersecting social units, their functions were entirely distinct and no conflict of loyalties resulted from an individual's concurrent obligation to both these units. The village community was the frame work for economic cooperation, for the organization of feasts and communal worship, and for the functioning of this institution that served in the maintenance of law and order. The main function of the clan on the other hand was the regulation of marriage and the strengthening of the social cohesion of the larger units, which cut across the system of social organization based on locality.

The clans were exogamous groups which were distributed over large areas and dispersed throughout many village communities. Clan members were considered descendants of a common ancestor and were known by a common name. Descent in the clan was strictly patrilineal. However, women were not totally subordinate to the authority of men. They were generally quite able to hold their own. They asserted themselves on all matters of household and family life, and nothing in their attitude suggested that they owe their husband deference or obedience. It must be emphasized that the tribal woman's position as an equal partner and companion of her husband, was largely due to the importance of her contribution to the maintenance of the common households. In agriculture if it was the man who fellow and burnt the jungle, it was the woman who helped in preparing the ground. Both wife and husband sowed, but the tedious work of weeding fell mainly on women. The most valuable of the woman's contribution to the family's food supply, however, was the many 
edible roots, leaves and fruits, which she collected throughout the year. Thus though descent in the clan was on patrilineal lines women were accorded an important status in tribal society.

Each village community consisting of several such clans functioned as an effective socio-political unit. The Muttadari system which was later on imposed in this region neither affected nor altered this system except that a cluster of village communities formed a Mutta.

The boundaries of the Muttas were ill-defined in the tangled terrain. The Muttadar's home village formed the nucleus and most stable part of the Mutta. The village headman was responsible to the Muttadar, who himself became identified with the inhabitants in course of time. In fact, the Muttadari system united various hill-communities into compact groups. ${ }^{11}$ In this hierarchy, the burden of outside authority was never felt by the tribes. The Headmen never ruled their co-villagers, but were only the spokesmen and representatives of an intensely democratic community. The gradual extension of either the Muttadari system or Mansabdar's authority did not bring about any radical changes in tribal society. Though the tribes had to recognize the authority of an outside power and yield to the demand of revenue (which however was minimal), this was accepted because it did not result in direct interference with the tribal mode of life.

The Muttadar, village headman and the tribes affirmed their social equality and cohesion through a common cultural heritage. But once this balance started getting disturbed in the $19^{\text {th }}$ century, restlessness crept in. The social organization, the Muttadari system, village communities and clan relationship which were wellknit enabled the tribes to draw upon their traditions of tribal unit and cohesion to act as one against the $19^{\text {th }}$ century intruders, when the presence of the latter became an unbearable burden.

A simple economic system enabled the presence of cordial and coherent social organization based on egalitarian principle. Neither currency notes nor occupancy rights prevailed there. Trade and commerce were alien to their culture. The entire economy was based on hard-work and mutual understanding. The barter system did exist wherein articles were exchanged for another article. It was an economy based upon the principle of subsistence and survived on primitive methods of agriculture. Theirs was a simple moral economy within a closed and self-sufficient village community.

The absence of private ownership of land within the body of tribal society formed the basis for a sense of solidarity amongst the village communities. They recognized no private ownership of forest land. However, each village community possessed communally a tract of land, whose boundaries were usually marked by hill ridges, water courses or prominent trees.

The geographical location and the tangle of wooded hills offered little scope for stable forms of agriculture other than shifting cultivation (or podu-cultivation) on hill-slopes, which was practiced from time immemorial. After cultivating for a few harvests the land was left fallow and agricultural work started afresh on new ground. This practice of shifting cultivation led to a semi-nomadic life. At each new place, they erected field-houses or thatched huts for living, out of material taken from the surrounding jungle. After selecting a hillslope, they felled trees and then burnt a part of that jungle, work which took several days. The felling of the jungle was the work of the men; but men, women and children worked together in cleaning-up and burning the fields followed by sowing. The plough was not used but they used digging sticks for making holes to sow seeds of jowar and pulses and other seed grain which were scattered over the surface. The instruments used in the agricultural operation were bill-hook, axe, sickle and reaping knife. Sowing was preceded by a great feast (Bhoomi Devata Panduga), which culminated in solemn sacrifice offered to the earth mother.

The crops grown were jowar, millet (Jonna), red gram (kandi), maize, korra and other various kinds of grains and pulses. The sowing was done in such a manner that when the crop was grown the 'podu' resembled a garden rather than a grain field, due to multitude of crops which were all intermingled. By January, reaping and threshing of all kinds of crop would come to an end, concluding the agricultural year. This was a favorable time for weddings and for visiting relatives in other villages, indeed after any crop was reaped; the hill men visited other villages taking small quantities of the new grain to their near relatives.

The practice of shifting cultivation left the hill men with no leisure or energy for other productive occupation except the manufacture of very few articles which were essential. All the implements used in agricultural operations, in hunting or in cooking were manufactured by the members of each household. Men made their bows and arrows, wore baskets and mats, made gourd-bottles, skin-bags, dance-drum etc. The women plaited baskets and mats, fetched water and wood, looked after pigs, fowls and cattle. They were also responsible for the gathering of jungle produce.

Generally, the production of grain was sufficient to sustain a family throughout the year and even allowed the exchange of a small surplus to be used as barter. In lean years, however, even with the most careful husbandry, their store of grain ran out of stock before the arrival of the next crop and they lived exclusively on jungle produce. ${ }^{12}$ Ripe fruits, berries, cucumber, raw mushrooms etc., were consumed. Green vegetables and jungle produce were most plentiful during rains. Rats, mice, squirrels, small birds, lizards etc., were roasted and consumed. Gruel (jawa) was common food in he tribal household. Fish was also regularly consumed. 
As already mentioned, the absence of private property in forest land secured peace and solidarity among the tribes. The absence of regular allotment of land for cultivation did not lead to disputes or fiction as forest land was plentiful. As soon as the cultivator abandoned the field his claim lapsed automatically and the land reverting to jungle, returned to the joint possession of the community. When after ten or twelve years, the forest was sufficiently grown to warrant the land being once more taken under the axe, the one time possessor had no privileged claim and any other man could forestall him in cutting the jungle. In principle, in shifting cultivation, the abandonment of fields was a normal and recurrent process and no individual rights in land therefore endured. The absence of ownership rights meant that land could be neither bought nor sold. The arrangements were a matter of mutual and information agreement carried-on from one generation to the other.

Generally, in the several small communities of Rampa, where the social cohesion was great, several men of one settlement cultivated a whole hill-side jointly and divided the crop. This method was usually followed by brothers or brothers-in-law and particularly by families living under one roof. There was a cooperative effort in falling the jungle, in clearing and weeding the field, in sowing and reaping, but once the harvest had been garnered the grain was shared out. Sometimes, in some families all the grain was kept in a common store. In few other settlements, the men co-operated only in preparing a block of land for sowing and they divided it, into fields, and each house prepared to sow, tend and reap on its own. In fact, co-operation in the production and the gathering of food was one of the main links of social cohesion within the family and village community. Anything that affected one individual in turn affected the whole community. Even in consumption, the same co-operation was witnessed. Either during feasts or when on an animal hunt, the burden of preparation was shouldered by the whole community. An important characteristic of the tribal society was the liberal hospitality they extended to their neighbors and guests which enabled the establishment of a chain of contact throughout the hill-area.

Besides what was grown and the forest produces, toddy was an important element in their subsistence economy. Men, women and children consumed it. It was drawn by the hill people from date, Palmyra and sago palm trees. ${ }^{13}$ From March to June, when the fields had been cleared and food stocks were low, they almost lived upon Palmyra and sago palm toddy. They also prepared 'brew' from the rice and samai. ${ }^{14}$ Whether it was in worship, ceremonies or in entertaining guests, these local toxic drinks were served and no festival ended without bouts of drinks and dance.

Given the mode of agriculture, domestication of animals did not receive a high priority. However, oxen and buffaloes were used by Koyas in rituals and ceremonies as supreme sacrificial animals, while hillreddies kept them at bay as eating of beef was considered a taboo. Goats and pigs were most commonly used in sacrifices and rituals and there were no taboos on the consumption of pork. It was the pig that was usually sacrificed to the earth goddess, as its blood was believed to fertilize the seed grain. These animals grazed in the jungle and their owners took no special efforts to bread them. Fowl was also an important item in ceremonies and rituals. There was no Deity to whom chicken was not acceptable. Occasionally, fines for special offences were as a rule expressed and paid in terms of pigs, goats and chicken. Dogs were sometimes used for hunting and received little care from their masters. It should be noted that domestication was a sideline that provided the hill-men now and then with the meat for a feast, but played, otherwise only an insignificant role in his system of food production.

Ever since they learnt the use of metal implements the tribes depended on craftsman of plains living on the fringes of the forests. These contacts led, no doubt, to other exchanges long before the pioneers of materially more advanced civilization began their thrust into the tribal country. The tribal exchange neither luxuries nor armaments but only necessary goods and even that as occasional transactions. In act they carried on little or no commerce. ${ }^{15}$

Hill Reddies exchanged baskets or grain against a knife or an axe with the Koyas. However, it was the blacksmith (Kammars), the main traders, who provided iron implements to both Koyas and Reddies and in return got grain. It must be noted that in this area neither Kammars nor Koyas smith mine or smelt iron, but only fashioned articles from metal procured from the plains or from traders.

The Malas, a low caste in the plains society, were active in the trade with the tribals. They were regular traders and spent many months of the year in touring the interior of the hills. They collected castorseeds, soap-nuts, tamarind, turmeric, honey, wax etc and occasionally also grain from the hill people in exchange for goods like pots, cloths, salt etc. The collected produce paid rich dividends to Malas. During bad harvests or when collecting provision for a wedding, a hill-man sometimes took grain or other commodity on credit from a Mala trader. The terms of the credit were very favorable to the Mala. For example, the hill-man was required to repay double the quantity borrowed the next year or mortgage his output of castor or other jungle produce to come. In these trade relations, it was the Malas who profited but the hill-man was seldom in serious debt. The Mala and Kammar traders from the plains in no way intruded directly into the moral economy of the tribes. Their interests did not necessitate the upsetting of the tribal world. Their barter trade was carried on within the frame-work of the tribal economy and hence resulted in no confrontation with the tribes. 
Thus in the absence of private ownership and accumulated wealth, the distinctions of rich and poor did not arise. It also limited the degree of socio-economic differentiation between Muttadar and his subject as the other members of the Muttadar family formed part and parcel of the tribal lot.

The revenue system was very simple. The Muttadar collected rents from the people for the lands actually cultivated and also got some presents annually in the shape of fruits or other hill produce or birds like parrots, hill mines, cranes, storks etc. ${ }^{16}$ To this were added a host of special fees on account of marriages, fines for offences, presents of game killed in the chase etc., which were paid by the villager without gumbling. ${ }^{17}$ They also rendered vetti service (unpaid labor) to the Muttadar, like cutting firewood, fetching water, sweeping and carrying loads. ${ }^{18}$ The Muttadar in turn paid very little revenue to the Mansabdar. This revenue was collected by the village headman on a joint-rent basis, each village paying its share fixed according to the number of households.

In fact, the consciousness that all the possessed was the fruit of his own labor is conveyed in his attitude towards his God. He prayed to them in order to avert disease or to obtain prosperity for his crops, which were largely dependent on factors outside his own control. His religion and rituals were geared to propitiate the deities for good crops, seasons and health. ${ }^{19}$

It is needless to say that forests played an important role in the life of tribes. It was the forest for the tribes, by the tribes and of the tribes. He loved jungle and was in turn loved and adorned by it. He was nature's child and like a loving mother, nature fed him, nursed him, lulled him, and protected him as mother ${ }^{20}$ He was the flower of the forest. ${ }^{21}$ It was their cradle, home and grave. It was the God or ghost, anything and everything. Transactions of every sort including the settlement of marriages took place in the interior. They never asked nor sought the help from the plains people. They were unconcerned with what was going on beyond their territory, collecting the minimum of what they wanted in daily life at their free-will and cultivating small patches of land to raise grain.

Their ideology, philosophy and world view nurtured in the forest interiors created in them a strong psychological and real fear of 'intrusion'. Geography of the region helped in strengthening such views and in maintaining the tribal in relative isolation from the plains. ${ }^{22}$

This isolation was shattered progressively through the $19^{\text {th }}$ century with the establishment of British control over this region. The dictates of colonial control and interests, gradually necessitated more and more direct intervention and control of the tribal world: the forests. This intervention was totally unlike previous intrusions from the plains. It brought in its wake new forms of exploitation, forms against which the tribes struggled though the $19^{\text {th }}$ century. The closed society and simple economy of the Rampa tribes provided a very conducive atmosphere for these struggles culminating into a major uprising in 1879-80.

\section{References:}

[1]. Generally the form of Government is either democracy, aristocracy or limited monarchy but "the concept of freeman is almost universal in the hill society", Jayant Bhushan Bhattachargee, Indian History Congress Proceedings, Aligarh, 1975, $36^{\text {th }}$ session, Reliable Printers, Calcutta, p.401.

[2]. Walter Kelly Firming (ed.), Affairs of the East India Company: $5^{\text {th }}$ Report from the Select Committee of the Publishing house, Delhi, 1984, p.23.

[3]. $\quad 5^{\text {th }}$ Report, op.cit, p.23.

[4]. Christopher Haimendorf, The aboriginal tribes of Hyderabad, The Reddies of the Bison hills, vol. II, Mac Millan and Co., London, 1945 , p.167.

[5]. a) Muttadar is the Chief of the Mutta, which in turn is a union of villagers of a "Sub-division of a Country", C.P. Brown Dictionary, Dialects, p.95, cited in J. Mangamma, Alluri Seetarama Raju, A.P. State Archives, Hyderabad, 1983, p.5.

b) For a detailed study of Muttadars position read No.744, $26^{\text {th }}$ March, 1888, Jdl

[6]. Christopher Haimendorf, op.cit., p.154.

[7]. A. Aiyappan, Report on the socio-economic conditions of the aboriginal tribes of the province of Madras, Govt. Press, Madras, 948, pp.25-26.

[8]. One example of the extent of influence exercised by Muttadar on his villagers can be had from the following lines "It will be extremely difficult to catch even one coolly in the jungle wilds, without the assistance of Muttadars", wrote O. Wolf Murray, Esq., Principle Assistant Agent, Vizagapatam, to the Agent to the Governor, dt. Lammasingi, $11^{\text {th }}$ August, 1887, Ex.No.14, No.744, 26 ${ }^{\text {th }}$ March, 1888, Jdl.

[9]. Surjit Sinha, "Tribal cultures of peninsular India as a dimension of the little tradition : A preliminary statement", cited in A.R. Desai (ed.), Rural Sociology in India, Popular Prakasham, Bombay, 1978, p.246.

[10]. Ibid, p.248.

[11]. David Arnold, "Rebellious Hill Men; the Gudem-Rampa uprisings, 1839 - 1924”, cited in Ranajit Guha (ed.), Subaltern Studies, vol. I, O.U.P., Delhi, 1982, p.98.

[12]. "The hill man is indeed especially blessed by the preservation in almost every jungle of fruit, vegetables, or roots to help him over a period of moderate scarcity", cited in Ramachandra Guha, Forestry and social protest in British Kumaun, 1893-1921.

[13]. W. Francis, Vizagapatam District Gazetteer, Madras, 1907, p.185

[14]. Ibid, p.187.

[15]. Fifth Report, op.cit., p.110.

[16]. C.L. Glanfurd, Report on the land Revenue settlement of the Upper Godavari District, Central Provinces, Nagpur, pp.56-60.

[17]. No.744, 26 ${ }^{\text {th }}$ March, 1888, Jdl.

[18]. C.L. Glanfurd, Op.cit., p.59.

[19]. a) W.Francis, op.cit., p.200. 
b) Even the human sacrifices that were offered were out of fear that the goddess may inflict the inhabitants of the region with disease. However, human sacrifice does not appear to be very deeply rooted in their culture.

[20]. V. Raghavaiah, Background of Tribal Struggles in India, cited in A.R. Desai (ed.).

[21]. V. Raghavaiah, 'Nomads', Swarajya Printing Works, Secunderabad, 1968, p.412.

[22]. To the British "Such traditional practices appeared totally inconsistent as it affected their forest resources", Neeladri Bhattacharya, "Colonial State and Agrarian Society", cited in S. Bhattacharya, R. Thapar (ed.), Situating Indian History for S. Gopal, O.U.P., Delhi, 1986, p.121. 